\title{
Formulation of Clay Refractory Bricks: Influence of the Nature of Chamotte and the Alumina Content in the Clay
}

\author{
Moustapha Sawadogo ${ }^{1,}$, , Mohamed Seynou ${ }^{1}$, Lamine Zerbo ${ }^{1}$, Brahima Sorgho ${ }^{1}$, \\ Gisèle Laure Lecomte-Nana ${ }^{2}$, Philippe Blanchart ${ }^{2}$, Raguilnaba Ouédraogo ${ }^{1}$ \\ ${ }^{1}$ Laboratory of Molecular Chemistry and Materials (LC2M), University Joseph KI-ZERBO, Ouagadougou, Burkina Faso \\ ${ }^{2}$ Institute of Research for Ceramic (IRCER), European Ceramic Centre (CEC), Limoges, France
}

\section{Email address:}

sawtapha22@yahoo.fr(M. Sawadogo), seynou1mohamed@yahoo.fr (M. Seynou), lamine_zerbo@yahoo.fr (L. Zerbo),

Sobrah20@yahoo.fr (B. Sorgho), gisele.lecomte@unilim.fr (G. L. Lecomte-Nana), philippe.blanchart@unilim.fr (P. Blanchart),

raguiloued@yahoo.fr (R. Ouédraogo)

${ }^{*}$ Corresponding author

\section{To cite this article:}

Moustapha Sawadogo, Mohamed Seynou, Lamine Zerbo, Brahima Sorgho, Gisèle Laure Lecomte-Nana, Philippe Blanchart, Raguilnaba Ouédraogo. Formulation of Clay Refractory Bricks: Influence of the Nature of Chamotte and the Alumina Content in the Clay. Advances in Materials. Vol. 9, No. 4, 2020, pp. 59-67. doi: 10.11648/j.am.20200904.11

Received: October 22, 2020; Accepted: November 5, 2020; Published: November 23, 2020

\begin{abstract}
Refractory materials from kaolinitic clays and clay chamotte or quartz were studied to increase the refractoriness under load at temperature above $1300^{\circ} \mathrm{C}$. Two different clays mined in Burkina Faso were used and chamotte grains were obtained by preliminary firing a local clay. Fired materials at $1350-1400^{\circ} \mathrm{C}$ present a typical granular composite microstructure where large grains of chamotte or quartz are embedded in the clay matrix phase. Under load at high temperature, the behavior of material is influenced by the nature of the clay matrix phase that progressively melt at high temperature, the type of chamotte or quartz grains, the grain sizes of different phases and the sequence of the thermal transformations during firing. Kinetics of creep under a constant load were characterized against temperature and time. It gives the typical temperatures at fixed creep strains, that's a well-recognized method for the refractoriness quantification. It's shown that the kinetic of creep change with the variation of viscosity with temperature of the melted clay matrix phase, that's related to both the chemical composition and the extend of the micro-composite nature of the heat transformed clays. Results also indicated that values of activation energy for creep are correlated to the refractoriness of materials.
\end{abstract}

Keywords: Clay, Chamotte, Mullite, Refractoriness

\section{Introduction}

Most of refractory bricks are silicate ceramic materials that are composed of clays and different silicate or aluminate mineral compounds. The most used clay raw materials contain kaolinite mineral due to the high temperature of the first liquid appearing from this mineral and from the reaction with commonly associated minerals as quartz or feldspar. Refractory bricks are used to ensure the thermal insulation of machineries and industrial equipment, to reduce thermal losses, corrosion from hot gases and liquids, and to protect workers from hot surfaces $[1,2]$. Particularly, the ceramic industry commonly uses kiln insulating materials that are resistant up to the temperature of $1500^{\circ} \mathrm{C}$. Refractory materials are also used for filtering hot gases and some of them like crucibles for melting metals or glasses [3, 4]. Both the refractoriness, the thermal shock resistance, the mechanical resistance and the physico-chemical stability at high temperature are very important in a large number of industrial applications [5]. However, the high degree of physical properties results from the composition of mixed mineral phases, but also from the type of processes used for the material fabrication [6].

In this work, refractory blocks for high temperature kiln casing were obtained in a pilot plan at the University Joseph KI-ZERBO of Ouagadougou. Refractory ceramic materials are mainly composed of kaolinite clays as a mineral binder and large grains of chamotte obtained from preliminary fired kaolinite clays. Since material properties depend mainly on 
the chemical and mineralogical composition of the raw materials, the objective of this work is the study of changes in physicochemical, mineralogical and thermal properties of refractory materials when firing temperature and raw type are changed.

All mineral materials are from local resources in Burkina Faso. Two kaolinite clays and sand were preliminary selected. One clay was selected for the chamotte fabrication process. Ceramic materials were obtained from adequate mixtures of clays and chamotte or sand that are shaped to form blocks, fired at high temperature and characterized.

\section{Materials and Methods}

The clays used in this work are named as SAB and TIK clays. They are issued from deposits in Sabcé and Tikaré, villages in the North Central region of Burkina Faso. Geographical coordinates of SAB are $13.23^{\circ}$ North and $1.54^{\circ}$ West and that of TIK are $13^{\circ} 16^{\prime}$ North and $1^{\circ} 43^{\prime}$ 'West. For specific compositions, one sand (quartz) was obtained in a deposit in the Bobo-Dioulasso area, the geographical coordinates are $11^{\circ} 10$ North and $4^{\circ} 17$ West.

The chemical analyses of SAB and TIK clays, and of sand were determined by ICP-AES.

The mineralogical analyses were obtained by $\mathrm{X}$ Ray diffraction with a Brüker D5000.

The process of chamotte fabrication from clay is similar to that commonly used [7]. The clay plastic paste (water content of $21.5 \mathrm{wt} \%$ ) is homogenized by extrusion, dried at $100^{\circ} \mathrm{C}$, and fired at $1300^{\circ} \mathrm{C}, 1$ hour.

Granulometry of clays were measured by laser diffusion in a water suspension ( $1 \mathrm{Vol} \%$ ) after a dispersion stage by US sonification.

Grain size distributions of chamotte and quartz sand were obtained by sieving between $100 \mu \mathrm{m}$ and $5 \mathrm{~mm}$.

Microstructural observation of the sintering samples was obtained using Scanning Electronic Microscopy (SEM; HITACHI SC-2500). The accelerating voltage varied from 10 to $30 \mathrm{kV}$.

Three types of refractory compositions were obtained according to the following processes:

a. the chamotte was crushed and sieved to obtain various fractions of size;

b. three compositions named SAB-Ch, SAB-Q and TIKCh were obtained as in table 1 ;

c. water was added to mixtures to obtain a semi-plastic paste (17 to $20 \mathrm{wt} \%$ of water) and kept into hermetic bags for 24 hours.

Prismatic blocks were shaped with a size of $5 \times 5 \times 5 \mathrm{~cm}^{3}$ by uniaxial pressing in a metal mold (mechanical press MagnolfiBigali with a peak pressure of $10 \mathrm{MPa}$ ). After pressing, blocks were dried at ambient atmosphere for 24 hours, at $65^{\circ} \mathrm{C}$ during 12 hours and at $110^{\circ} \mathrm{C}$ during 24 hours. After drying, they were fired at different temperatures $(1250,1300,1350$ and $1400^{\circ} \mathrm{C}$ ) during two hours with a heating rate of $3^{\circ} \mathrm{C} / \mathrm{min}$.
Table 1. Composition of bricks.

\begin{tabular}{lll}
\hline Code & Binder & Chamotte or sand \\
\hline SAB-Ch & $60 \mathrm{wt} \%$ Clay SAB & $40 \mathrm{wt} \%$ chamotte \\
TIK-Ch & $60 \mathrm{wt} \%$ Clay TIK & $40 \mathrm{wt} \%$ chamotte \\
SAB-Q & $60 \mathrm{wt} \%$ Clay SAB & $40 \mathrm{wt} \%$ Sand \\
\hline
\end{tabular}

The physicochemical properties of fired materials were characterized as follows:

a. after firing, the density and the open porosity of blocks were determined according to the requirement of ISO 10545-3 standard [8];

b. the linear shrinkage was obtained with the measurement of Lv (length of blocks after drying) and Lc (length of blocks after firing).

c. the compressive strength was obtained from the uniaxial stress up to the rupture stress. A ramp of 0.5 mm. min $^{-1}$ was used for the applied strain.

The compressive creep of blocks was carried out by measuring the resistance under load (RUL) according to the standard ISO 1893 [9]. Blocks were cut in a cylindrical form (diameter $50 \mathrm{~mm}$ and height $50 \mathrm{~mm}$ ). A uniaxial hot-pressing process was used with a constant load of $0.2 \mathrm{MPa}$ and a heating ramp of $5^{\circ} \mathrm{C} / \mathrm{min}$. The uniaxial strain was recorded with temperature up to $1500^{\circ} \mathrm{C}$.

Activation energy can be expressed using the Arrhenius rate equation [10].

$$
\dot{\varepsilon}=\mathrm{d} \varepsilon / \mathrm{dt}=A_{\mathrm{o}} \sigma^{\mathrm{n}} \exp \left(-E_{a} / R T\right)
$$

where, $\varepsilon=d L / L_{o}(\%), \dot{\varepsilon}=d \varepsilon / d t$ is the creep rate $\left(\mathrm{s}^{-1}\right), \mathrm{A}_{\mathrm{o}}$ is a constant, $\mathrm{n}$ the creep stress exponent, $E_{a}$ the activation energy, $\mathrm{R}$ the gas constant and $\mathrm{T}$ the temperature $(\mathrm{K})$.

The activation energy can be determined by equation (1) that is rewritten for variable temperature with constant stress:

$$
\begin{aligned}
\dot{\varepsilon}_{1}=\mathrm{d} \varepsilon / \mathrm{dt}= & \mathrm{A}_{0} \sigma_{1}^{n} \exp \left(-E_{a} / \mathrm{RT}_{1}\right) ; \dot{\varepsilon}_{2}=\mathrm{d} \varepsilon / \mathrm{dt}=\mathrm{A}_{0} \sigma_{1}^{n} \exp \left(-E_{a} / \mathrm{RT}_{2}\right) \\
& \dot{\varepsilon}_{1} / \dot{\varepsilon}_{2}=\exp \left[-E_{a} / \mathrm{R}\left\{\left(1 / \mathrm{T}_{2}\right)-\left(1 / \mathrm{T}_{1}\right)\right\}\right]
\end{aligned}
$$

and

$$
E_{a}=\left[\mathrm{RT}_{1} \mathrm{~T}_{2} \ln \left(\dot{\varepsilon}_{1} / \dot{\varepsilon}_{2}\right)\right] /\left(\mathrm{T}_{2}-\mathrm{T}_{1}\right)
$$

\section{Results}

Chemical analyses are reported in table 2. For both clays, alumina and silica are predominant phases, as for most of kaolinite minerals mixed with quartz. The significant quantity of $\mathrm{K}_{2} \mathrm{O}$ is mostly related to a mica phase as illite. Both chemical compositions of SAB and TIK clays are in the range of many argillaceous raw materials used for the production of ceramic refractories. The content of $\mathrm{Al}_{2} \mathrm{O}_{3}$ is between 20 to $45 \mathrm{wt} \%, \mathrm{TiO}_{2}$ is between 1 to $4 \mathrm{wt} \%, \mathrm{Fe}_{2} \mathrm{O}_{3}$ is not exceeding $2.5 \mathrm{wt} \%$ and the sum of alkaline and alkaline earth elements $\left(\mathrm{Na}_{2} \mathrm{O}, \mathrm{K}_{2} \mathrm{O}, \mathrm{CaO}\right.$ and $\left.\mathrm{MgO}\right)$ does not exceed $4 \mathrm{wt} \%[1,11,12]$. A simple comparison of the two chemical compositions in table 2 suggests that the refractoriness of TIK clay is the highest since its $\mathrm{Al}_{2} \mathrm{O}_{3}$ content is higher than that of SAB clay.

The chemical composition of the sand is also in table 2 . It 
shows a very high content of silica ( $86.67 \mathrm{wt} \%)$, but a small quantity of alumina, probably from the presence of a residual

quantity of clay.

Table 2. Chemical composition of SAB, TIK and Sand.

\begin{tabular}{llllllllll}
\hline Oxides (wt\%) & $\mathbf{S i O}_{2}$ & $\mathbf{A l}_{2} \mathbf{O}_{3}$ & $\mathbf{C a O}$ & $\mathbf{K}_{2} \mathbf{O}$ & $\mathbf{M g O}$ & $\mathbf{N a}_{2} \mathbf{O}$ & $\mathbf{T i O}_{2}$ & $\mathbf{F e}_{2} \mathbf{O}_{3}$ & $\mathbf{L O I}^{*}$ \\
\hline $\mathrm{SAB}$ & 69.09 & 20.55 & - & 1.45 & 0.12 & 0.49 & 0.95 & 0.85 & 6.43 \\
$\mathrm{TIK}$ & 62.42 & 24.6 & 0.08 & 1.5 & 0.21 & - & 1.09 & 1.73 & 8.21 \\
Sand & 86.67 & 9.82 & 0.13 & 0.07 & 0.05 & 0.16 & 0.3 & 0.1 & 2.7 \\
\hline
\end{tabular}

* Loss On Ignition at $1000^{\circ} \mathrm{C}$.

$\mathrm{X}$ ray patterns of clays in figure 1 show that $\mathrm{SAB}$ and TIK contain quartz, kaolinite, and illite as major minerals. Besides, the content of minor minerals as iron or titanium minerals are low and cannot be really identified by the X Ray technique.

From the chemical analysis (Table 2) and the identification of phases in figure 1, we propose the semi-quantitative mineralogical analysis of table 3 .

Table 3. Semi-quantitative analysis of SAB and TIK.

\begin{tabular}{llllll}
\hline Samples & Kaolinite (wt\%) & Quartz (wt\%) & Illite (wt\%) & Total (wt\%) & Balance (wt\%) \\
\hline SAB & 40 & 45 & 13 & 98 & 2 \\
TIK & 50 & 33 & 13 & 96 & 4 \\
\hline
\end{tabular}

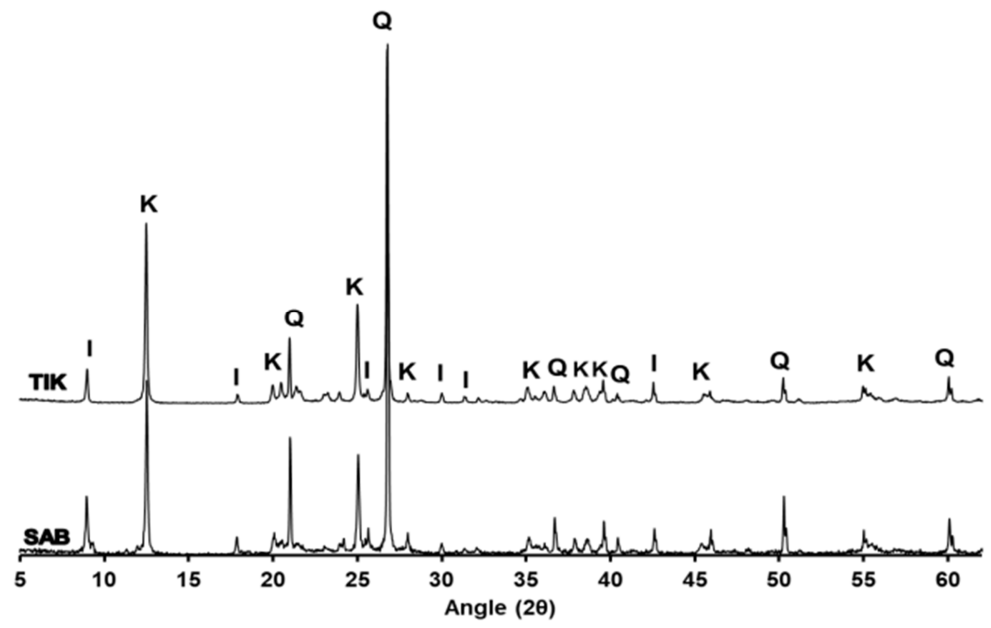

Figure 1. X-ray patterns of clay TIK and clay SAB. K: kaolinite; Q: quartz; I: illite.

Figure 2 (a) is the distribution of grain sizes in SAB and TIK clays. It is seen that the average grain size of TIK is larger than $\mathrm{SAB}$ one. Both clays have a similar curve shape with a large peak centered in the size range of less than 10 $\mu \mathrm{m}$ and another pic centered at a higher value for TIK. The latter pic indicates the presence of larger size of grains. As for all clays, the small grain size population is mainly made up of clay minerals and the large grain size populations are non-clay minerals. In general, the large grain size population comes mainly from quartz. This means that TIK contains a significant amount of relatively large quartz grains. The fired chamotte undergoes a controlled crushing process to obtain the granulometry distribution of Figure 2 (b). The grain size distribution is very similar to that of the quartz sand, and this work was published in the journal of the West-African Chemical Society [7].
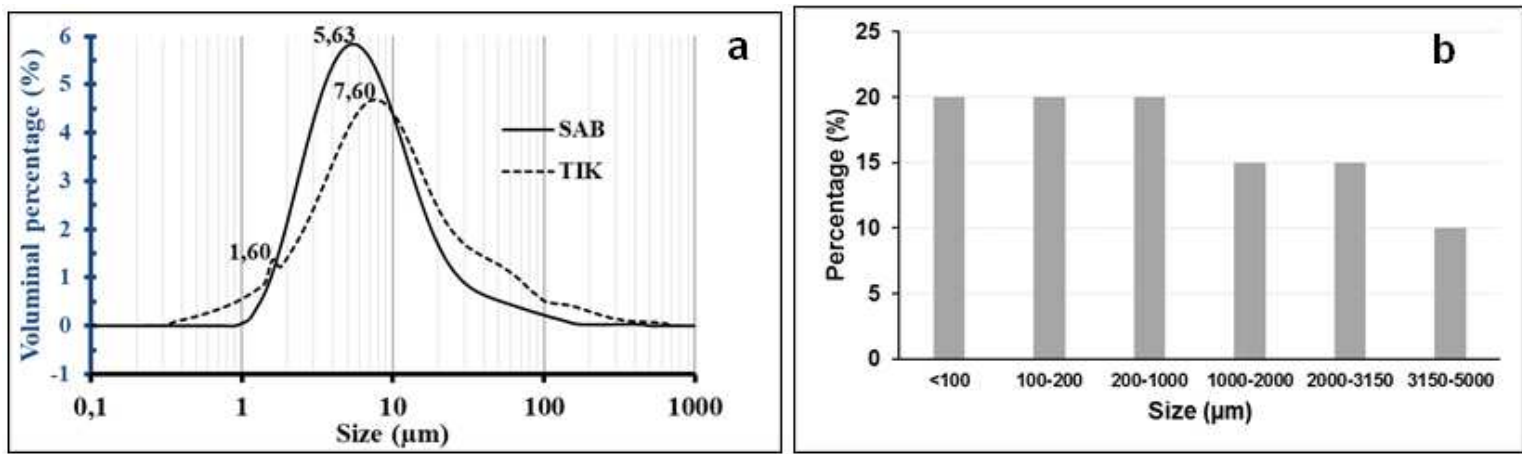

Figure 2. Particle size distribution of the samples: (a) Clays; (b) chamotte or sand. 


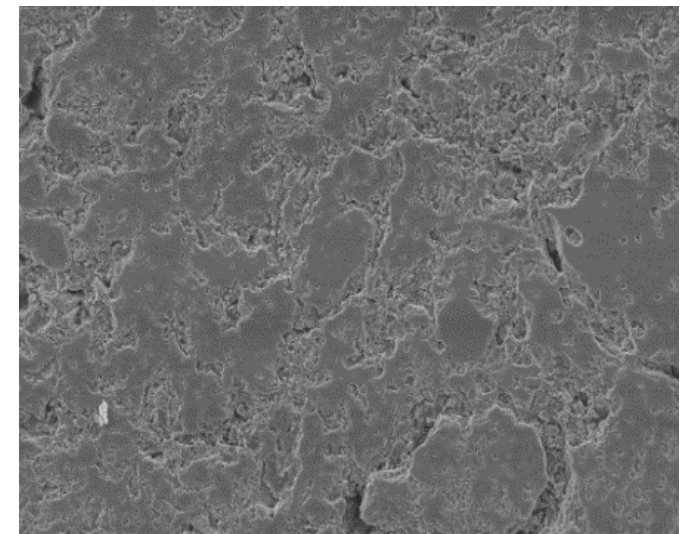

Figure 3. SEM image of the specimens $S A B$-Ch after sintering at $1400^{\circ} \mathrm{C}$.

In Figure 3, the microstructural observation of SAB-Ch shows evidences the micro composite nature of phases in refractories. Such microstructural characteristic is similar to that of all fired materials. We clearly observe the dense and large grains of chamotte that are distributed within the clay matrix phase. Porosity is mostly distributed in the matrix phase, and some remaining large pores are within matrixchamotte interfaces.

In figure 4 the linear shrinkage according to the temperature depends on the composition. The mixture of clay and sand (SAB-Q) undergoes a small shrinkage even at high temperature $\left(1.5 \%\right.$ at $\left.1400^{\circ} \mathrm{C}\right)$. Similar linear shrinkage values are also observed in the literature [13].

Figure 5 shows the change of open porosity with temperature for the three materials. In general, porosity is high despite of the high firing temperature. Only the SAB-Ch present a limited open porosity at temperatures above $1350^{\circ} \mathrm{C}$.

The changes of bulk density are in figure 6 for the three types of mixtures. The SAB-Ch presents density values above that of other compositions whatever the temperature. The SAB-Q has a density lower than $2 \mathrm{~g} / \mathrm{cm}^{3}$ between $1250^{\circ} \mathrm{C}$ and $1350^{\circ} \mathrm{C}$. The TIK-Ch have the lowest density that change only slightly in the whole temperature range.

The compressive strength values for the whole temperature range are in figure 7. The compressive strength of SAB-Q is increasing slightly with temperature until a maximum value of $21.5 \mathrm{MPa}$ at $1350^{\circ} \mathrm{C}$. The compressive strength is significantly increased above $1300^{\circ} \mathrm{C}$ for SAB-Ch and above $1350^{\circ} \mathrm{C}$ for TIK-Ch.

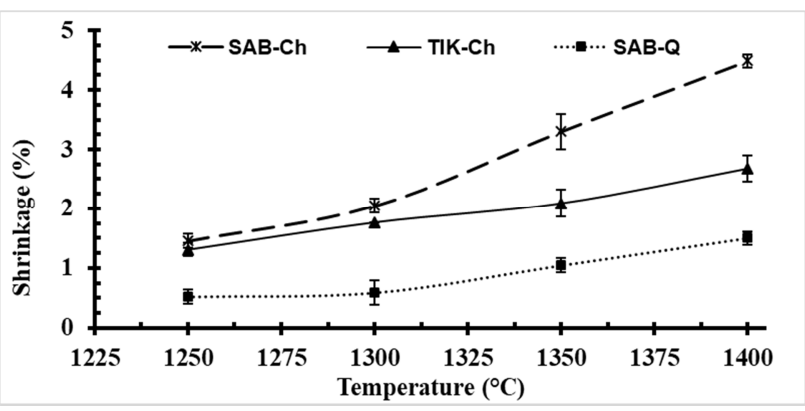

Figure 4. Linear shrinkage of the bricks according to temperature.

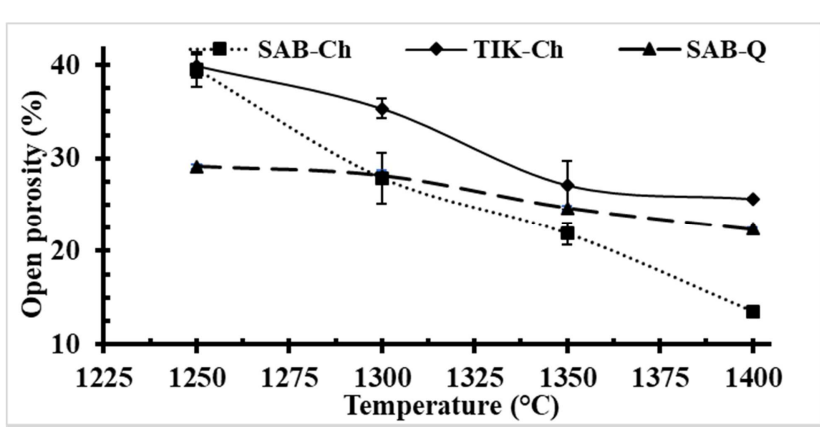

Figure 5. open porosity of bricks according to temperature.

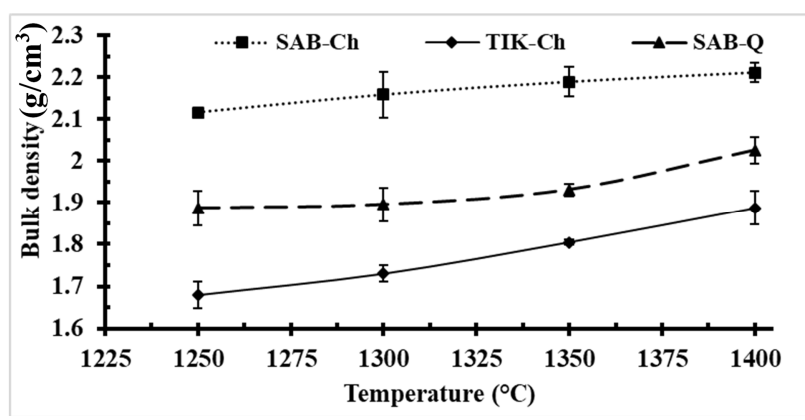

Figure 6. Bulk density of the bricks according to temperature.

The structural transformations are analyzed by $\mathrm{X}$ ray diffraction. Patterns for the heat-treated mixtures fired at $1350^{\circ} \mathrm{C}$ are in figure 8 . The major phases occurring in the three materials are cristobalite, mullite and quartz.

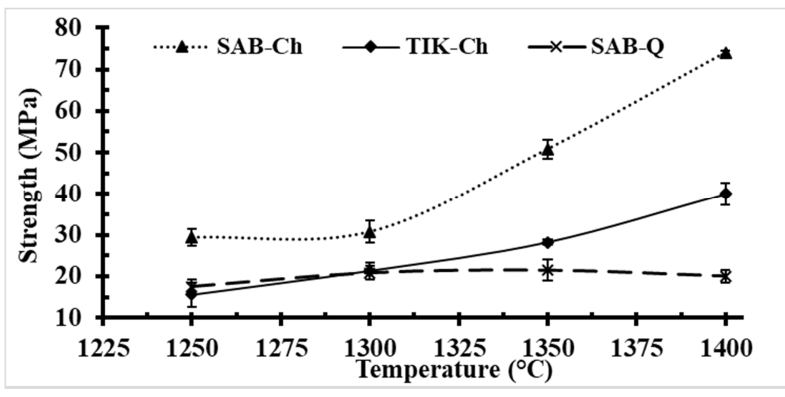

Figure 7. Compressive strength of bricks at $30^{\circ} \mathrm{C}$.

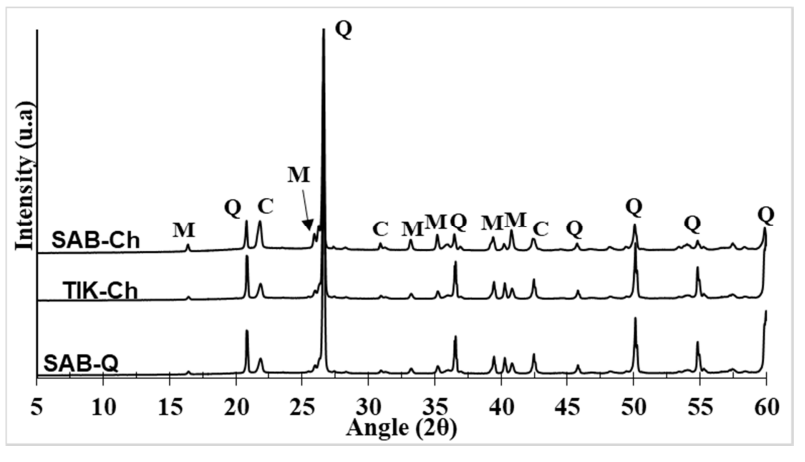

$\mathrm{Q}=$ quartz; $\mathrm{M}=$ mullite $\mathrm{C}=$ cristobalite.

Figure 8. X-ray patterns of the three compositions of bricks at $1350^{\circ} \mathrm{C}$.

The refractoriness under load (RUL) with temperature is plotted in figure 9 for $\mathrm{SAB}-\mathrm{Ch}$ fired at $1400^{\circ} \mathrm{C}$. It is a typical curve very representative of other materials. 
A calibration of creep values $\left(\mathrm{L} / \mathrm{Lo}_{\text {cor }}\right)$ was obtained using dense alumina as a reference sample. Reference temperature corresponding to fixed values of relative deformations $(0.5,1$, 2, 5 length\%) are obtained in each corrected curve, and they are reported in table 4 . These reference temperatures are very useful for the comparison of the behavior with temperature of different refractories under load (RUL). It is the most used technique to characterize the maximum working temperature under compressive stress [14].

In figure 10 , relative strain changes above $900^{\circ} \mathrm{C}$ are plotted, evidencing the strong differences in material behaviors.

Table 4. Characteristic temperatures of RUL of specimens fired at $1350^{\circ} \mathrm{C}$ and $1400^{\circ} \mathrm{C}$.

\begin{tabular}{|c|c|c|c|c|c|}
\hline Temperature & Specimen & $\mathrm{SAB}-\mathrm{Ch}$ fired at $1350^{\circ} \mathrm{C}$ & SAB-Ch fired at $1400^{\circ} \mathrm{C}$ & TIK-Ch fired at $1400^{\circ} \mathrm{C}$ & SAB-Q fired at $1350^{\circ} \mathrm{C}$ \\
\hline $\mathrm{T}_{0.5}\left({ }^{\circ} \mathrm{C}\right)$ & & 1387 & 1426.2 & 1393.3 & 1173.6 \\
\hline $\mathrm{T}_{1}\left({ }^{\circ} \mathrm{C}\right)$ & & 1408.9 & 1443.4 & 1425 & 1320.4 \\
\hline $\mathrm{T}_{2}\left({ }^{\circ} \mathrm{C}\right)$ & & 1426.4 & 1457.2 & 1443.3 & 1416.6 \\
\hline $\mathrm{T}_{5}\left({ }^{\circ} \mathrm{C}\right)$ & & 1449.1 & 1477.4 & 1463.2 & 1462.8 \\
\hline
\end{tabular}

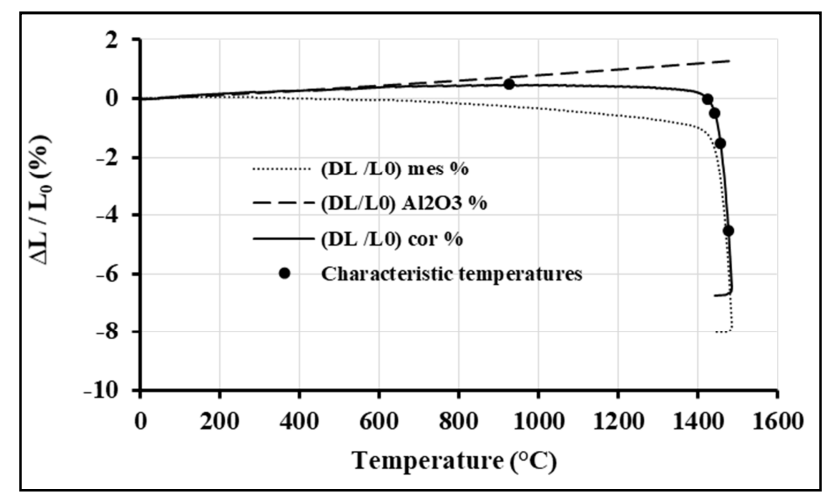

Figure 9. Experimental and corrected refractoriness under load curves of SAB-Ch fired at $1400^{\circ} \mathrm{C}$.

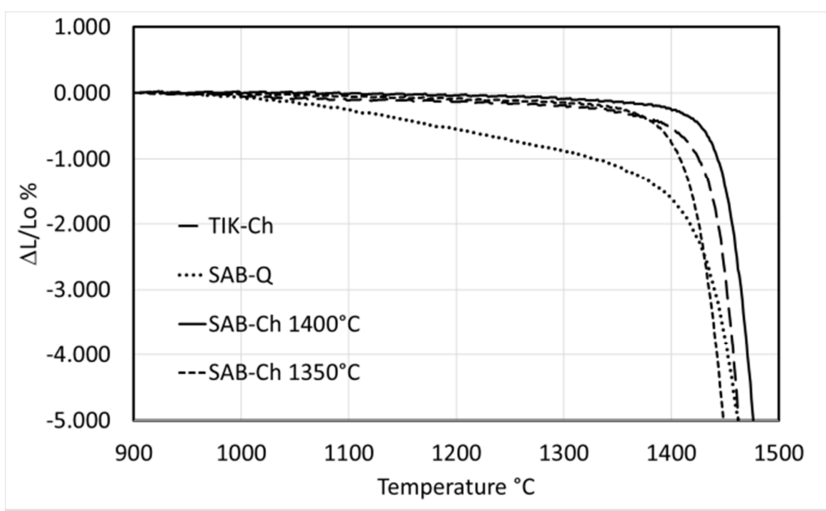

Figure 10. Comparison of refractoriness under load curves of refractories against temperature. The relative strain variations are from $900^{\circ} \mathrm{C}$.

The activation energy values were determined by plotting the creep at a constant temperature as a function of time.
Figure 11 presents the curve for the behavior of SAB-Ch at the temperature of $1408^{\circ} \mathrm{C}$. In figure 12 the use of equation (2) gives the activation energy from the slope of the straight line. Resulting values are reported in table 5.

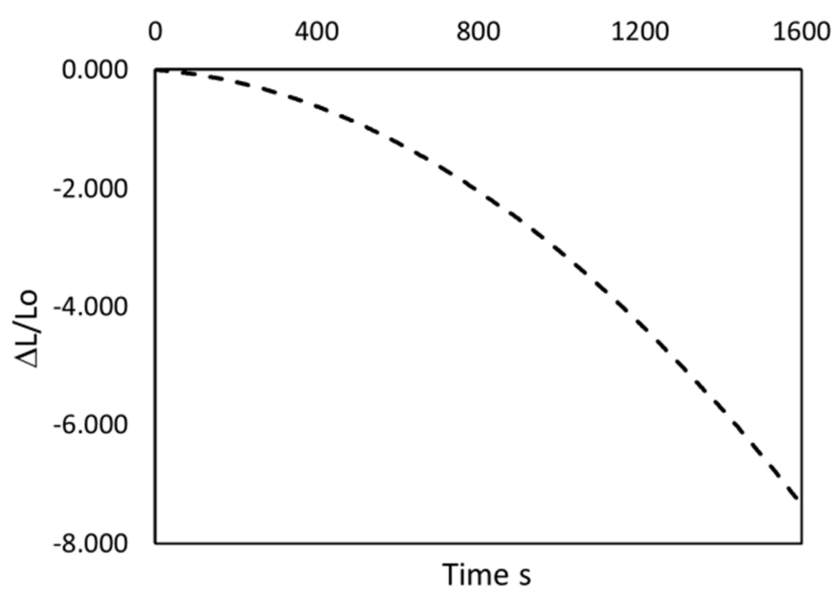

Figure 11. Creep curve of $S A B-C h$ at $1408^{\circ} \mathrm{C}$ against time.

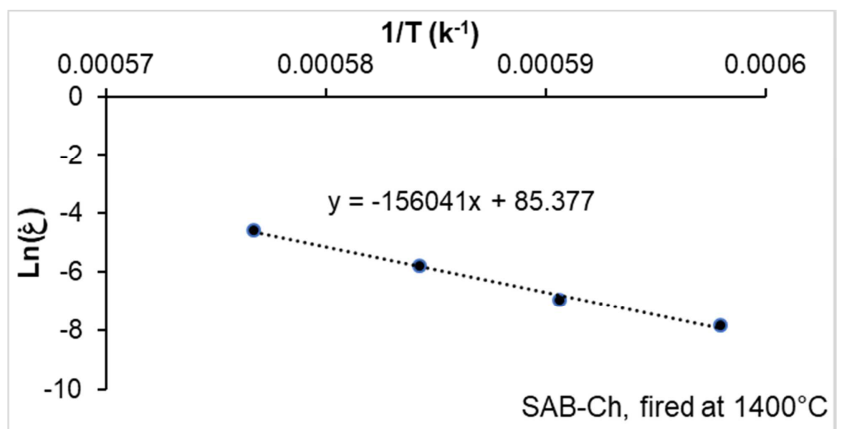

Figure 12. typical variation of $\operatorname{Ln}(\varepsilon)$ versus the reverse temperature.

Table 5. Activation energy of specimens fired at $1350^{\circ} \mathrm{C}$ and $1400^{\circ} \mathrm{C}$.

\begin{tabular}{lllll}
\hline Samples & SAB-Ch fired at $\mathbf{~ 1 3 5 0}^{\circ} \mathbf{C}$ & SAB-Ch fired at $\mathbf{1 4 0 0}^{\circ} \mathbf{C}$ & TIK-Ch fired at $\mathbf{~ 1 4 0 0}^{\circ} \mathbf{C}$ & SAB-Q fired at $\mathbf{1 3 5 0}{ }^{\circ} \mathbf{C}$ \\
\hline Activation Energy $(\mathrm{kJ} / \mathrm{mol})$ & 603.4 & 778.9 & 718.3 & 558.6 \\
\hline
\end{tabular}

\section{Discussion}

SEM image of figure 3 evidences the typical microstructure of refractory bricks with TIK clay or SAB clay, and chamotte or quartz after firing at $1400^{\circ} \mathrm{C}$. A micro- composite microstructure is shown with big grains of chamotte or quartz that are distributed in a fired clay matrix phase. In general, the thickness of interfaces of matrix phase is a little less than the size of chamotte or quartz grains.

Creep process under load up to $1500^{\circ} \mathrm{C}$ is the main test that characterize the Refractoriness Under Load (RUL). It is 
a very important characterization that is related to the composition, the microstructural characteristics, the physicochemical properties of phases and the processing methods.

During the sintering process at $1350^{\circ} \mathrm{C}$ or $1400^{\circ} \mathrm{C}$, some phases changes occurred: above $1050^{\circ} \mathrm{C}$, a progressive structural transformation of quartz into cristobalite. This is shown through XRD pattern of figure 8 where the cristobalite peak at $2 \theta \approx 22^{\circ}$ is more intense for SAB-Ch.
Simultaneously, the mullite quantity also increases as shown with peak height at $2 \theta \approx 35,2^{\circ}$, and it is more noticeable with SAB-Ch.

In general, quantities of mullite and silica are increased with temperature from the progressive transformation of the phyllosilicates minerals as kaolinite, above $1050^{\circ} \mathrm{C}$ (reaction 1) [7].

$$
\text { Metakaolinite }\left[6\left(\mathrm{Al}_{2} \mathrm{O}_{3}, 2 \mathrm{SiO}_{2}\right)\right] \stackrel{\approx 980^{\circ} \mathrm{C}}{\longrightarrow} 6 \mathrm{SiO}_{2}+\text { Spinel phase }\left[3\left(2 \mathrm{Al}_{2} \mathrm{O}_{3}, 2 \mathrm{SiO}_{2}\right)\right] \stackrel{\left(>1050^{\circ} \mathrm{C}\right)}{\longrightarrow} 8 \mathrm{SiO}_{2}+\mathrm{Mullite}_{2}\left[2\left(3 \mathrm{Al}_{2} \mathrm{O}_{3}, 2 \mathrm{SiO}_{2}\right)\right] \text { reaction1 }
$$

Above $980^{\circ} \mathrm{C}$, a transient spinel phase is progressively transformed into mullite and the reactive silica is involved in different structural transformations. Particularly, a glassy phase often results from the reaction at high temperature with alumino-silicate phases containing alkaline elements. For the potassium oxide, it is mostly from illite mineral in both SAB and TIK clays [5, $14-17]$. The reaction sequence with temperature is given by reaction 2 ;

$$
\text { Mica mineral }\left[\mathrm{K}_{2} \mathrm{O}, 3 \mathrm{Al}_{2} \mathrm{O}_{3}, 6 \mathrm{SiO}_{2}, 2 \mathrm{H}_{2} \mathrm{O}\right] \stackrel{>1140^{\circ} \mathrm{C}}{\longrightarrow} \text { Mullite }+ \text { melted glassy phase } \quad \text { reaction } 2
$$

Simultaneously during structural transformations and the formation of melted phase, different physical transformations occurred during the sintering process. They are primarily influenced by the chamotte and alumina contents in materials.

Figure 4 shows that the linear shrinkage with temperature is increased continuously. ParticularlyTIK-Ch composition has a small dimensional variation that is favorable to the control of shape and size of the fired materials. It is related to a higher kaolinite content in mineralogical composition and a reduced quartz content.

In figure 5 , it is obvious that the variation of open porosity, is correlated to the shrinkage variations in Figure 4. However, the SAB-Ch has a very limited porosity that is a favorable property in use of this refractory.

For the particular composition of SAB-Q, the open porosity is lower than that of $\mathrm{SAB}-\mathrm{Ch}$, for all the temperature range used. It is from the very dense nature of quartz grains that are less porous than the chamotte grains.

Density values at figure 6 , corroborate the data of open porosity. The TIK-Ch has the lowest density that it is related to a feeble shrinkage and a higher porosity. The density of the SAB-Ch is the highest, since the open porosity is small. It should favor an improved resistance into aggressive environments at high temperature.

The SAB-Q has a low density that is related to the specific behavior of quartz grains. During the successive thermal cycles for sintering and for creep tests, a part of quartz grains is transformed into cristobalite. Quartz and cristobalite undergone repetitively the structural transformations at $573^{\circ} \mathrm{C}$ and $220^{\circ} \mathrm{C}$ during successive heating and cooling stages. These phenomena induce local volume variations and mechanical constrains at quartz grain surfaces that result in voids between larger quartz grains and the matrix phase. During creep test, interfacial voids are the ways for the rearrangement of large quartz grains and for a liquid flow at interfaces.

From figure 7, the compressive strength of the material is high for SAB-Ch fired at $1350^{\circ} \mathrm{C}$ or $1400^{\circ} \mathrm{C}$, and also for the
TIK-Ch fired at $1400^{\circ} \mathrm{C}$. SAB-Ch fired at $1400^{\circ} \mathrm{C}$ has the higher compressive strength that is related to a higher density (Figure 6) and a lower porosity (Figure 5). A similar correlation is seen with TIK-Ch and SAB-Q.

The creep strain with temperature under a constant load is quantified with the values of fixed temperatures reported in table 4. Particularly, the temperature $\mathrm{T}_{0.5}$ is the temperature corresponding to the onset of softening and at $\mathrm{T}_{2}$, there is a noticeable strain. For all materials $\mathrm{T}_{0.5}$ is above $1350^{\circ} \mathrm{C}$, as it is stated in the literature since $\mathrm{T}_{0.5}$ is considered as a reference temperature [18, 19]. According to P. Pilate, the refractoriness of materials depends on the chemical composition of the samples [19]. However, the alumina content is just only one of the refractoriness key factors since it decreases strongly with the content of some elements as $\mathrm{Na}_{2} \mathrm{O}, \mathrm{K}_{2} \mathrm{O}, \mathrm{MgO}, \mathrm{TiO}_{2}, \mathrm{Fe}_{2} \mathrm{O}_{3}$. It also depends on the sintering temperature and the composition of large grains. In general, $\mathrm{T}_{0.5}$ increases with the sintering temperature and decreases with the porosity value.

The influence of the sintering temperature of materials is noticeable. $\mathrm{T}_{0.5}$ is $1387^{\circ} \mathrm{C}$ for $\mathrm{SAB}-\mathrm{Ch}$ sintered at $1350^{\circ} \mathrm{C}$, and becomes $1426.2^{\circ} \mathrm{C}$ for the same material sintered at $1400^{\circ} \mathrm{C}$. The value for TIK-Ch is $1393.3^{\circ} \mathrm{C}$ although it is sintered at $1400^{\circ} \mathrm{C}$. The lowest value is $1173.6^{\circ} \mathrm{C}$ with $\mathrm{SAB}-$ $\mathrm{Q}$ sintered at $1350^{\circ} \mathrm{C}$, that could be related to the low apparent density. After firing and during the creep process at high temperature, a macroscopic creep occurs from the rearrangement of the refractory big grains network, and from viscous flow and sliding at interfaces between big grains [20]. For a small strain, RUL is mostly controlled by the matrix phase behavior at high temperature since refractory large grains of chamotte or quartz are supposed to behave without deformation in the temperature range of experiments.

The interfacial matrix phase is found in zones between grains, as thin layers along grain boundaries. It forms with temperature a glassy phase resulting from transformations with temperature of the initial phase composition. It is mostly heat transformed clays and quartz, and newly crystallized phases, as cristobalite and mullite [21]. Interactions between 
phases promotes a progressive and continuous recrystallization process of mullite and cristobalite (Figure 8). Quantities of phases depend strongly on starting composition, temperature, and thermal history [19].

As the temperature increases the viscosity of the glass phase decreases, allowing creep to occur by viscous flow. This process still occurs as long as the large grains become interlocked. However, Figure 3 evidences the significant thickness of the intergranular phase where a slow and continuous viscous flow occur during experiments.

In general, the behavior and strain with temperature of thick intergranular phases depends strongly on two main parameters:

a. the viscosity of the glass melted phase that can be calculated, knowing the chemical composition [22];

b. the relative quantities of glass and crystalline phases.

However, the chemical composition of the melted phase in silicate ceramics is continuously changed with temperature and time. This phenomenon has been observed with clay ceramics where the glass phase composition was analyzed by WDS [23]. Besides, the quantity of crystalline phases can be obtained by quantitative $\mathrm{XRD}$, although they are also continuously changed with time and temperature.

With the studied refractories, we cannot determine the exact compositions of the glass phases, but it is possible to find the range of possible glass compositions in the studied temperature range. In the lower limit at about $1100^{\circ} \mathrm{C}$, melted compositions are in the most representative phase diagrams in the silicate systems $\mathrm{SiO}_{2}-\mathrm{Al}_{2} \mathrm{O}_{3}-\mathrm{K}_{2} \mathrm{O}$ and $\mathrm{SiO}_{2}-\mathrm{Al}_{2} \mathrm{O}_{3}$ $\mathrm{Na}_{2} \mathrm{O}$ [24]. In the $\mathrm{K}_{2} \mathrm{O}$ system, the predominant liquid phase is a peritectic liquid at $1140^{\circ} \mathrm{C}$ and in the $\mathrm{Na}_{2} \mathrm{O}$ system, it is a eutectic liquid at $1062^{\circ} \mathrm{C}$. For the upper temperature limit at about $1500^{\circ} \mathrm{C}$, the melt composition is close to the chemical compositions of clays, in Table 2 .

The range of viscosity against temperature of the glass phase can be calculated with well-known statistical models, and results are presented in Figure 13 [22, 25]. Such statistical models are based on numerous experiments, with the general form:

$$
T_{I}=K_{0}+\sum_{j=1}^{n}\left\{K 1_{j} C_{j}+\sum_{k=j+1}^{n}\left(K 2_{k} C_{j} C_{k}+\sum_{m=j+k+1}^{n} K 3_{m} C_{j} C_{k} C_{m}\right)\right\}
$$

where $T_{I}$ is the temperature for a given viscosity, and $K 0, K 1$, $K 2$ and $K 3$ are coefficient related to single components of the glass and associated components. $C_{j}$ are the concentration of components in the melted phase composition.

In Figure 13, the eutectic and peritectic liquids in the $\mathrm{K}_{2} \mathrm{O}$ and $\mathrm{Na}_{2} \mathrm{O}$ systems behave similarly, showing viscosities < $10^{3.2} \mathrm{~Pa}$. s at temperature above $1300^{\circ} \mathrm{C}$. The occurrence of low viscosity liquids is correlated with the onset of the accentuated strain seen in figure 9. This increased creep is also verified with all clay-chamotte materials.

However, the intergranular phase is mostly a composite material where crystalized mullite and cristobalite are distributed in the glass phase. In that case, the apparent viscosity is increased, depending on the content of crystallized particles. It can be represented by the Krieger and Dougherty relation where the relative viscosity $\eta_{\mathrm{r}}$ depends on the volume fraction $ø$ of the crystalline phases in the glass, and in the critical volume fraction $\emptyset_{c}$ at the percolation threshold [26]:

$$
\eta_{r}=\left(1-\frac{\emptyset}{\emptyset_{c}}\right)^{-B \emptyset_{c}}
$$

$B$ is the Einstein constant, with a commonly accepted value of 2.5 .

With SAB and TIK clays the volume fraction $\varnothing$ of the crystalline phases at high temperature are obtained from chemical compositions in table 2 and from XRD data of figure 8 . The fraction of crystalline phase is 0.55 for $\mathrm{SAB}$ and 0.37 for TIK, which are below the critical volume fraction of 0.64 at the percolation threshold.

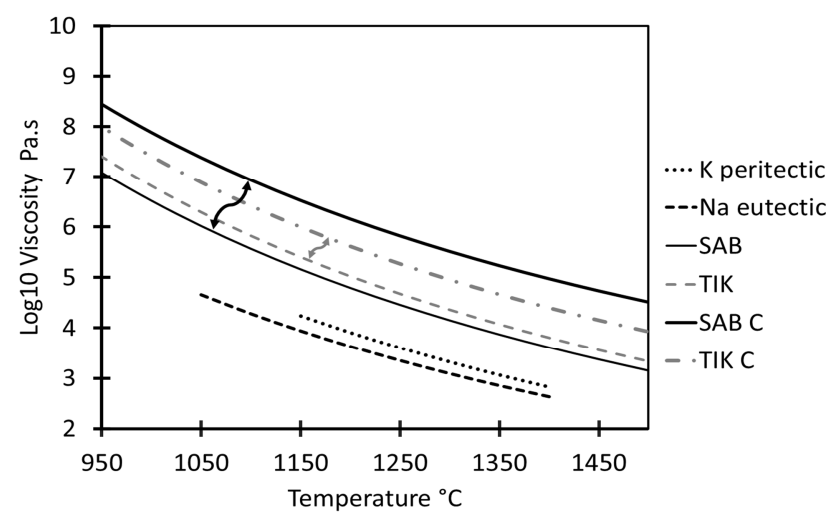

Figure 13. Viscosity against temperature of $K$ peritectic, Na eutectic, melted $S A B$ and TIK clays, and composites of SAB and TIK with crystalized cristobalite and mullite phases.

In figure 13, the upper limits of the viscosity range of the intergranular phases were obtained from equation 5. It is seen that a significant shift of viscosity occurs for TIK and SAB clays, towards higher viscosity. The shift for SAB is the most accentuated one and the curve has a reduced slope with temperature. It explains the lower creep strain with temperature of the composition SAB-Ch fired at $1400^{\circ} \mathrm{C}$. The refractoriness of SAB-Ch materials fired at $1400^{\circ} \mathrm{C}$ is high since it can be used at temperature up to $1400^{\circ} \mathrm{C}$ with a reduced permanent strain.

Refractoriness is also related to the activation energy. From table 4 and table 5, we note that the activation energy is higher for the SAB-Ch specimens although the lower alumina content. These results must be related to the interpretation of A. Terzié et al and H. Rhanim et al that state an increased value of activation energy for refractory bricks with an increase of alumina content [27, 28]. However, decreased values with higher alkaline contents are also explained. It shows that the high activation energy value of SAB-Ch can be related to its lower impurity content.

Table 4 and table 5 also evidence that the increase of $\mathrm{T}_{0.5}$ temperatures induces an increase of the activation energy $E_{a}$. It is explained from the general description of silicate melts using an Arrhenius-type equation:

$$
\ln \eta_{a p p}=\ln A_{a p p}+\alpha \ln T+\frac{E_{a}}{R T}
$$


$T$ is the absolute temperature, $A_{\text {app }}$ is a model parameter, $\alpha$ is an equation constant.

It means that the increase of the silicate melt viscosity is related to the increase of the activation energy for creep, and to the increase of the refractoriness with $\mathrm{T}_{0.5}$ temperature.

\section{Conclusion}

Three types of refractory materials were obtained by compaction of mixture of raw clays with large grains of chamotte or quartz sand. After firing at $1350-1400^{\circ} \mathrm{C}$, it gives granular composite materials. The study is devoted to how refractoriness is controlled by both the nature and distribution in the microstructure of the clay matrix phase and the large grains of chamotte or quartz. The macroscopic physicochemical, mineralogical and thermal characteristics are related to the temperature of sintering, to the alumina content, to the nature and size of the largest grains that are distributed in the matrix phase, and to the clay acting as binder phase.

With SAB clay, a higher refractoriness is obtained when chamotte ( $\mathrm{SAB}-\mathrm{Ch})$ is used, and for a sintering temperature of at $1350^{\circ} \mathrm{C}$ or more. The density exceeds $2.1 \mathrm{~g} / \mathrm{cm}^{3}$, the open porosity is below $22 \mathrm{vol} \%$ and the compressive strength attains $49 \mathrm{MPa}$.

However, with TIK clay mixed with chamotte, a lower refractoriness is obtained although the clay contains a higher alumina content than that of SAB clay. The density decreases to $1.91 \mathrm{~g} / \mathrm{cm}^{3}$, the open porosity is higher than $27 \mathrm{vol} \%$ and the compressive strength decreases to $26 \mathrm{MPa}$. Replacing chamotte by a quartz sand continue to further reduce the refractoriness, and the compressive strength decreases to $21 \mathrm{MPa}$.

Data of refractoriness under load are correlated to densification curve against temperature. It is shown that the material SAB-Ch fired at $1350^{\circ} \mathrm{C}$ has the highest softening temperature of $1387^{\circ} \mathrm{C}$. It results from the specific behavior of the SAB clay matrix phase at interfaces and at high temperature. In general, clay matrix phase has a viscous behavior above about $1100^{\circ} \mathrm{C}$ that induces creep under load. For SAB clay, the apparent viscosity is increased due to the presence of small sized crystalline phases (mullite, cristobalite) within the glassy phase. It reduces significantly the kinetics of creep under load above $1300^{\circ} \mathrm{C}$.

\section{References}

[1] Jacques Poirier: Les céramiques réfractaires de l'élaboration aux propriétés d'emploi. Verres Céramiques et Composites. Volume 1, 28-42, (2011). https:// reue-vcc.univ-setif.dz.

[2] Abla Mecif, Julien Soro, Abdelhamid Harabi, Jean Pierre Bonnet: Preparation of Mullite- and Zircon-Based Ceramics Using Kaolinite and Zirconium Oxide: A Sintering Study. Journal of the American Ceramic Society 93 (5), 1306-1312, 2010. https://doi.org/10.1111/j.1551-2916.2009.03595.x.

[3] Bahia Rabehi: Evaluation des propriétés réfractaires et cimentaires du kaolin de Djebel Debbagh. Thèse de l'université de M'Hamed Bougara-Boumerdes; (2013). http://dlibrary.univ-

boumerdes.dz:8080/handle/123456789/1259.

[4] Edwige Yeugo-Fogaing, Marc Huger, Thierry Chotard, Christian Gault: Caractérisation de l'endommagement d'origine thermique de réfractaires de type électrofondu par techniques acoustiques à haute température. Matériaux 2006, Dijon, France. 7 p. https://hal.archives-ouvertes.fr/hal00144564

[5] G. Aliprandi: Matériaux réfractaires et céramiques techniques. Editions Septima, Paris (1979).

[6] Mohamed Seynou, Pierre Flament, Moustapha Sawadogo, Jacques Tirlocq, Raguilnaba Ouedraogo: Refractory bricks based on Tikaré (Burkina Faso) kaolinitic raw clay material: J. Soc. Ouest-Afr. Chim. 035, 49-56, (2013). http://www.soachim.org.

[7] M. Sawadogo, M. Seynou, L. Zerbo, B. Sorgho, A. Yameogo, Y. Millogo, R. Ouedraogo: Densification behaviour of chamotte chamotte for refractory bricks: mineralogy and microstructure. J. Soc. Ouest-Afr. Chim. (2016) 041; 1-10. http://www.soachim.org.

[8] Norme ISO 10545-3: Détermination de l'absorption d'eau, de la porosité ouverte, de la densité relative apparente et de la masse volumique globale. https://www.iso.org/fr/standard/68006.html

[9] ISO 1893: 2007: Produits réfractaires - Détermination de l'affaissement sous charge - Méthode différentielle avec élévation de la température. Novembre 2008. https://www.iso.org/fr/standard/44297.html.

[10] Anne Hynes and Robert Doremus: Theories of creep in ceramics: American Ceramic Society Bulletin, Vol. 86, ${ }^{\circ} 8$, 129-187, 2006. https://doi.org/10.3929/ethz-b-000419735

[11] N El Yakoubi, M Aberkan, M Ouadia: Potentialité d'utilisation d'argiles marocaines de Jbel Kharroudans l'industrie céramique. C. R. Geoscience 338 (2006) 693-702. https://doi.org/10.1016/j.crte.2006.03.017

[12] Sayel M. Fayyed, Ghazi S. Al-Marahleh, Suleiman Q. AbuEin: Improvement of the Refractoriness under Load of FireClay Refractory Bricks. Adv. Theor. Appl. Mech., Vol. 5, no.

4, $\quad 161 \quad-\quad$ 172, https://doi.org/10.1016/j.renene.2012.01.094 Z

[13] A. Benlalla, M. Elmoussaouiti, M. Dahhou, M. Assafi: Utilization of water treatment plant sludge in structural ceramics bricks. Applied Clay Science, Volume 118, December 2015, Pages 171-177. https://doi.org/10.1016/j.clay.2015.09.012

[14] A. P. Luz, D. T. Gomes, V. C. Pandolfelli: Maximum working temperature of refractory castables: do we really know how to evaluate it? Ceramics International 43 (2017) 9077-9083. 10.1016/j.cermint.2017.04.053

[15] C. Y. Chen, G. S. Lan, W. H. Tuan: Microstructural evolution of mullite during the sintering of kaolin powder compacts. Ceramics International 26, 715-720, (2000). https://doi.org/10.1016/S0272-8842(00)00009-2.

[16] B. Amrane, E. Ouedraogo, B. Mamen, S. Djaknoun, N. Mesrati: Experimental study of the thermo-mechanical behaviour of alumina-silicate refractory materials based on a mixture of Algerian kaolinitic clays. Ceramics International 37, 3217-3227, (2011). http://dx.doi.org/10.4236/jsemat.2015.52009. 
[17] Mohamed Seynou, Younoussa Millogo, Raguilnaba Ouedraogo: White paste for stoneware tiles for pavement using raw clay material from Burkina Faso. Mater. Struct. 46, 755-763, https://link.springer.com/article/10.1617/s11527-012-9932-0.

[18] Jochen Allenstein, Peter Bartha, Heinz Barthel, Carola BattMichel, and Fred Brunk: Refractory materials: Pocket Manual; Design, Properties, Testing. Gerald Routschka, Hartmut wuthnow $3^{\text {rd }}$ Edition; (2008).

[19] P. Pilate, V. Lardot, F. Cambier, E. Brochen: Contribution to the understanding of the high temperature behavior and of the compressive creep behavior of silica refractory materials. Journal of the European Ceramic Society 35 (2015) 813-822. https://doi.org/10.1016/j.jeurceramsoc.2014.09.019.

[20] Eric Blond, Nicolas Schmitt, François Hild, Philippe Blumenfeld, Jacques Poirier. Modeling of high temperature asymmetric creep behavior of ceramics. Journal of the European Ceramic Society, Elsevier, 2005, 25 (11), 18191827. https://doi.org/10.1016/j.jeurceramsoc.2004.06.004.

[21] Kévin Boussois, Nicolas Tessier-Doyen, Philippe Blanchart. High-toughness silicate ceramic. Journal of the European Ceramic Society, 2014 pp. 119-126. https://doi.org/10.1016/j.jeurceramsoc.2013.07.024.

[22] A. Kondratiev, A. V. Khvan, Analysis of viscosity equations relevant to silicate melts and glasses. Journal of Non-
Crystalline Solids $432 \quad$ (2016) 366-383. https://doi.org/10.1016/j.jnoncrysol.2015.10.033.

[23] Tengfei Deng, Baijun Yan, Fangjun Yang: Measurements and model application on the viscosities of liquid phase in clay based ceramics. Journal of the Ceramic Society of Japan 127 310-317 2019. http://doi.org/10.2109/jcersj2.18189.

[24] Levin, E. M. Phase diagrams for ceramists. Columbus, Ohio: American Ceramic Society, (1956) https://catalog.hathitrust.org/Record/102443473.

[25] A. Fluegel: "Glass Viscosity Calculation Based on a Global Statistical Modeling Approach"; Glass Technol.: Europ. J. Glass Sci. Technol. A, vol. 48, 2007, no. 1, p 13-30. https://www.ingentaconnect.com/content/sgt/gta/2007/000000 48/00000001/art00003.

[26] I. M. Krieger and T. J. Dougherty: A mechanism for nonNewtonian flow in suspensions of rigid spheres. Trans. Soc. Rheol., III: 137-152, 1959. https://doi.org/10.1122/1.548848.

[27] A. Terzié, L. Pavlovié, A. Milutinovié-Nikolic: Influence of the phase composition of refractory materials on creep. Science of sintering, 38 (2006) 255-263. doi: $10.2298 / \mathrm{SOS} 0603255 \mathrm{~T}$.

[28] H. Rhanim, C. Olagnon, G. Fantozzi, A. Azim: Etude du comportement thermomécanique du zircon: Revue de Mécanique Appliquée et Théorique, Vol. 1, 4. 227-238 (2003). https://hal.archives-ouvertes.fr/hal-00475131. 